\title{
The domestic dimension of sports diplomacy ${ }^{\star \star}$
}

\section{Introduction}

Political utility of sport has been gaining rising attention among scholars and political decision-makers lately. Because of enormous global popularity, sports events can serve as convenient channels of communicating identity of nations to the external publics. Sport can be used to boost country's international prestige, advertise its assets for example as a tourist destinations, or to shape international relations. Apart from its external political significance, sport can also play a number of internal roles within society. Sport is believed to play a role in integrating society (Werner, 1989: 20), fostering the processes of nation-building (Keim, 2003), or serving as a tool of strengthening the legitimization of the ruling elite. Development of sports policy was also aimed to enhance productivity of the society (this was typical for communist states) and to improve the general level of health among the people of a country in response to problems of modern societies such as obesity.

Political and social importance of sport is meaningful. It is interesting though that its external and internal political roles are usually investigated separately. The objective of the research is to overview key types of sports diplomacy activities pursued by governments from the perspective of their internal political significance. The hypothesis to be verified within the research states that sports diplomacy, despite being a foreign policy tool, is not separated from internal policy.

\section{Domestic dimension of sports diplomacy - theoretical approach}

Sports diplomacy is a category without a single understanding, with a number of definitions highlighting different elements. In its most narrow conceptualization sports diplomacy is understood as a tool of interstate relations. In this sense sports diplomacy can

\footnotetext{
* Correspondence address: Katedra Teorii Polityki i Myśli Politycznej, Instytut Studiów Politologicznych, Uniwersytet Łódzki, 90-131 Łódź, ul. Lindleya 3, Polska, e-mail: michal.kobierecki@uni.lodz.pl.

** The research has been financed by National Science Centre, Poland, within project number 2015/19/D/ HS5/00513.
} 
be viewed as a way of making friends and managing conflicts (Rowe, 2011: 115), or in a wider way, as a whole range of international contacts between people connected with sport and politicians, that are motivated by foreign policy concerns and have implications for general relations between states (Merkel, 2017: 29). Within such understanding of sports diplomacy we may distinguish its positive and negative forms, depending whether sport is used to make the relations between states better or worse.

Besides reference to sport as a tool of managing interstate relations, sports diplomacy can also be understood in other way. The second understanding of sports diplomacy refers to its role in promoting states - shaping their desired international perception, or legitimizing new or contested states (Trunkos, Heere, 2017: 13-14). This paper for obvious reasons refers to these two aspects of sports diplomacy, as they are strongly associated with governments attempts to use sport for the sake of realizing state's external objectives - as a means of shaping relations with other countries and fostering state's international prestige and image.

Stuart Murray and Goeffrey Pigman, apart from the use of sport by governments as a diplomatic instrument, distinguished a category of 'international sport as diplomacy', by which they meant diplomatic representation, communication and negotiation between non-state actors that take place as a result of ongoing international sporting competition (Murray, Pigman, 2014: 1099). In other words, sports diplomacy can also be understood as diplomacy in which sports bodies are engaged. This type of sports diplomacy will not be taken into consideration, though, since the research is focussed on states' activities.

Sports diplomacy is perceived as a sub-category of public diplomacy (Johns, 2014: 7-8; Black, Peacock, 2013: 709). The latter term has been subject to research within the field of international relations for many years. According to James Pamment, public diplomacy means communication of an international actor's policies to citizens of foreign countries (Pamment, 2013: 1). Beata Ociepka stated that public diplomacy is one of the forms of political communication which is directed to wider group of recipients than traditional diplomacy, which main objective is to affect the public opinion in another country and as a result directly to affect its government (Ociepka, 2008: 11-13).

Public diplomacy is by its nature a tool of shaping external perception of a state, building trust and sympathy towards it. It is important to note though, that according to various authors, public diplomacy also has its internal dimension which is connected to interactions with domestic public. Such domestic public diplomacy is believed to be a purely political tool with such potential benefits as creating public understanding and support for government's policy and consolidating its overall credibility and legitimacy. It is worth pointing out that including a domestic dimension of public diplomacy does not separate it from the international component (Huijgh, 2016: 437). It is more about reaching external and internal political goals simultaneously with the use of the same method. 
The concept of internal dimension of public diplomacy laid theoretical foundations for this research. Since sports diplomacy is believed to be a sub-category of public diplomacy, it should also have its internal dimension. Scholars investigating sports diplomacy tend to understand existence of the domestic dimension of sports diplomacy, but on the other hand overlook it in their research (Murray, 2018: 9). This may refer to both to the use of sport in order to shape relations with other states, and to employing sport as a means of shaping international image of a state.

\section{Sport as a tool of shaping inter-state relations}

As has been noted, one of the narrow ways of understanding sports diplomacy limits its scope to the use of sport in order to shape relations with other states. Under this approach it is, therefore, means of fostering foreign policy goals and supplementing traditionally perceived diplomacy. Within such sports diplomacy, positive and negative activities might be distinguished. Positive sports diplomacy is about using sport in order to build international bridges, create opportunities for political rapprochement and deepening proximity between states. Negative sports diplomacy, on the other hand, is about using sport as a means striking political opponents, for example through sports boycott or sports isolation. In both cases the mechanism is similar to public diplomacy - with the use of sport and activities associated to sport a state, directly or indirectly (as it may operate through grassroots initiatives), sends a particular message to the society of another country.

A question might appear about the place for domestic dimension of sports diplomacy if it is a communication towards external actor. Once again we need to refer to theoretical considerations on public diplomacy. Firstly, according to certain researchers it is, especially in its contemporary form, a two-way communication between states (Gilboa, 2008: 55-58). It is, therefore, not simply a communication from state A to state B, but rather a communications between states A and B. Sports diplomacy directed at affecting relations between states is quite similar. One of the most important cases of such sports diplomacy is the famous Ping-Pong diplomacy between United States and China. A visit of American table tennis national team to China was used to facilitate political opening between the two states since both of them were interested in getting closer but because of many reasons including international prestige were not ready to engage in traditional diplomacy. The key point here is that it was neither a step taken exclusively by the US nor by China. No matter who initiated the exchange (although it still remains unclear) both sides were engaged and had their objectives.

If Ping-Pong diplomacy is considered, according to Murray and Pigman, the main motivation was about testing whether public opinion in both countries would accept new opening in mutual relations (Murray, Pigman, 2014: 1101). Such motivation is explicitly internal, regardless international character of the exchange. It was the Chinese government that was interested in preparing its society to rapprochement with the Unit- 
ed States, since it would be facing consequences of an 'unprepared opening.' From this perspective, Ping-Pong diplomacy was about influencing the society domestically, with external relations in mind.

Virtually any example of employing sports diplomacy in order to shape relations between states can be analyzed through the perspective of engaging domestic public, although obviously in various situations the strength of such engagement was different. An important example of sports importance in shaping bilateral relations refers to Turkey and Armenia, whose presidents attempted to use football matches within FIFA World Cup qualifications to foster political rapprochement between the two states which did not hold diplomatic relations and had a closed border. Presidents of Armenia, Serzh Sarkisyan, and Turkey, Abdullah Gül, paid visits to other countries to watch football matches and at the same time to hold diplomatic talks (Gunter, 2011: 130;134). Although the whole endeavour did not lead to a lasting enhancement of bilateral relations, it gave a chance for it. Through the so-called football diplomacy Turkish president communicated to Armenians and vice versa, but at the same time the Armenian elites were using this opportunity to test whether the public opinion was ready for a breakthrough. The external dimension of sports diplomacy was, therefore, just as important as its internal dimension.

The domestic dimension is, therefore, fairly clear if positive sports diplomacy aimed at shaping international relations is considered. It is, however, not that clear within negative sports diplomacy. As has been noted, it refers to the use of sport for instance in order to communicate dissatisfaction with the policy of particular government and can be observed through sports isolation or boycott. Such activities by governments or national sports bodies might have certain domestic effects, for example by consolidating the society against a common enemy. For instance, when Jimmy Carter declared American boycott of the Moscow Olympic Games in 1980, American public opinion was decidedly in favour of the idea (Macintosh, Hawes, 1994: 97). According to some authors, Carter's decision might have been connected to the approaching elections and his need to show himself as a strong leader (Drachman, Shank, 1997: 213-124). Therefore to some extent domestic dimension of such negative sports diplomacy is also visible, but to lesser extent than in its positive form. This is connected to the direction of communication within respective types of sports diplomacy. Positive sports diplomacy ultimately is a two-way communication, with two sides potentially benefiting from the contact. In such cases one side's external objectives are often similar to another side's internal goals. Negative sports diplomacy is confrontational by its nature and represents a one-way communication which is more typical of propaganda or Cold-War style public diplomacy. Of course the presence of such domestic dimension is dependent on particular situation including internal goals of the government, situations concerning elections, characteristic qualities of relations between engaged states. Still, in such cases internal dimension of sports diplomacy is also visible. 


\section{Sport as a tool of building international image of a state}

Another form of sports diplomacy associated with states' activity is about the use of sport in order to shape international image of a state. Basically there is a number of methods of such political use of sport. The most important include hosting sports events and sports victories. Apart from them, sports exchanges, sports development aid, participation in sport, sports investments and recognisability of sport can be mentioned (Kobierecki, 2018: 271). Virtually any of them are explicitly external activities, but also have domestic dimensions.

Hosting sports events is one of the most important ways of employing sport for the sake of building international prestige of a state. They are believed to be a rare opportunity to present state's identity in the global media (Dembek, Włoch, 2014: 35). Organizing them, particularly when mega-events are considered, became the key factors of developing local and national branding strategies (Grix, Brannagan, Houlihan, 2015: 468). Through attracting global attention host city or nation might show to the global audience their merits, send particular messages, for instance about internal changes or development, or tackle negative stereotypes. Nation branding and public diplomacy significance of sports event is, therefore, indisputable.

Hosting sports events also has a domestic dimension, and it is not only about developing local infrastructure, reforming economy, attracting tourists and foreign investments. In fact, domestic public is another recipient of the communication that is being held through hosting such events and goals such as strengthening national pride are often associated to them (Bodet, Lacassagne, 2012: 358-359). It was very clearly visible when sports events organized by China in recent years are considered. Events such as the Asian Games in 1990 or the Olympic Games in 2008 had explicitly external branding goals. The Asian Games, according to Chinese policy-makers, were supposed to show new China to the world, but at the same time the objective was to strengthen Chinese self-esteem (Hong, 2007: 83-84).

The Olympic Games in Beijing in 2008 are one of the most ultimate examples of using a sports event as a means of shaping desirable international perception of a state. In response to the assumption that China was perceived through contrasting elements, such as developing economy, modern metropolises and social transformation, and over-population, destroying environment and uneven distribution of wealth on the other side, the Games were supposed to educate the world on modern China and to shape an unified, positive image (Lai Lee, 2010: 209; Cull, 2008: 135). But the domestic aspect of this communication appears to be equally important. Internal goals of hosting the Beijing Olympics were connected to shaping relations between the government and the society in the context of building unity of the Chinese, considering growing social inequities (Yu, 2010: 2821-2841; Davies, 2011: 42). The Chinese as a nation can be characterized as the people with developed sense of dignity and the need of having a relevant status. 
Contrary to this, the country had been humiliated for a long time as a result of wars. The goal of the Communist Party of China was, therefore, to renew the former glory (Lai Lee, 2010: 208-209). This is partly connected to the modern Chinese nationalism and has explicitly domestic dimension, although similar motivation can be recognized in external goals of Chinese branding sports diplomacy. It is, thus, believed, that China needs public diplomacy activities in order to distance itself from economic and political systems from before the reforms, to counter negative and false stereotypes and to position itself as a regional leader (Lu, 2011: 29-30). The Beijing Olympic Games have, therefore, shown very clearly, that conducting sports diplomacy directed at communicating to external publics may serve similar purposes concerning the domestic public. What is more, it is sometimes difficult to say which motivations, external or internal, are more important.

A fairly similar situation might be attributed to the Olympic Winter Games in Sochi in 2014. External branding goals of the event were very clear and already at the bidding stage Russians claimed that the event was a great opportunity to enhance Russia's international reputation, a chance to counter the image of the 'red bear' and to present an international political and economic comeback. The Games were to show that Russia succeeded in modern capitalism (Orttung, Zhemukhov, 2014: 179). These goals have an explicit external character. However, other objectives, connected to the power of the nation and Wladimir Putin himself (Book, 2014: 45; Arnold, Foxall, 2014: 6), might be important both in external and internal dimensions.

Aspects of influencing Russia's public through the Sochi Games can be seen when some speeches of Russian political elites are evoked. Wladimir Putin stated, concerning the selection of Sochi as the future host of the Olympics: "without doubt, not just a recognition of Russia's sporting achievements but [...] a judgment on our country" (Müller, 2014: 154). He also commented it saying that it was an identification of "power and might of our country, of our desire to win" and that there was a "demand for our country in the international arena as a strong, autonomous, independent government with its own opinion" (Alekseyeva, 2014: 162). Such statements of the Russian president were rather common for Russian political elites and showcasing Russia's return to the status of a great power appeared to be one of the key objectives concerning hosting the Olympics (Persson, Petersson, 2014: 192; Golubchnikov, 2016: 184; Golubchnikov, Slepukhina, 2014: 167). Such motivations have an obvious external dimension, but the domestic one appears to be just as clear. It might be important for Russia to be seen as a great power by foreign public, but such feeling is at least similarly important for the Russians. The Sochi Olympics are, therefore, a good example of the domestic dimension of branding sports diplomacy.

The public diplomacy mechanisms of sports victories are fairly similar as within hosting sports events. Sports victories traditionally have been used by states to build international prestige, hence successes in sport are often perceived as indicators of the effica- 
cy of a state and its government, and the general prosperity of a country (Anholt, 2009). Such attitude to sport some scholars describe as ‘sports nationalism' (Koller, 2008: 1469). Similarly to hosting sports events, sports successes may also serve the purposes of influencing domestic publics. The case of Great Britain is a very good example for such situation. Originally government's engagement in pursuing sports policy was very limited in this country. This situation has changed in 1990s, partly in response to a very disappointing result of Team GB during the Olympic Games in Atlanta in 1990, were it won only one gold medal. Such poor performance was assessed as a disgrace for the British (Guthrie-Shimizu, 2013: 1761). This led to a significant raise of sports funding in the $\mathrm{UK}$ and astonishing results its national team achieved during recent Olympics. All this is connected to boosting international prestige of Great Britain, and to the need of sustaining national pride and unity of the society (Allison, Monnington, 2005: 17). Sports performance of Team GB could, therefore, be interpreted as a communication both to external and domestic publics simultaneously.

The similar issue could be observed regarding the Chinese performance during the Olympic Games in Beijing in 2008. Chinese were determined to win the Olympic medal table. Similarly as hosting the event, sports victory was meant to show Chinese abilities to the world, but at the same time to give the Chinese people a sense of pride and to reject the image of China as the 'sick man of Asia' (Cha, 2009: 3). This domestic dimension of athletes' results during the Games could be observed in Chinese media where the joint number of medals was not included - in this sense China lost to the United States (Wardęga, 2014: 63-64).

The domestic public diplomacy significance of sports victories was also visible during the Cold War era. For the Cold War superpowers and their allies, sports competition served as an important arena for mutual rivalry. Sports victories had obvious external objectives, for example connected to attracting the Third World countries, but were also supposed to serve the internal propaganda needs (Allison, 1994: 95). Many similarities might be recognized when contemporary Russia is considered. Sports victories, equally as hosting sports events, are believed to be one of national priorities as Russia's former president Dmitry Medvedev once said (Petersson, 2014: 36). Their political objective include restoring the national pride and dignity (Riordan, 2010:326), which belong to the main pillars of Wladimir Putin's policy and reasons for his popularity in Russia.

Hosting sports events and achieving successes in sport are the branding sports diplomacy tools reserved almost exclusively to powerful and big states. Participation in sport, on the other hand, is a means of employing sport for diplomatic purposes which is used by small, less powerful countries or those without international recognition. For them being able to compete in international sports event is important in order to "seek acknowledgement of their existence within the international system" (Houlihan, 2004: 219). Successful attempts to compete in major sports events also have a great internal meaning for such nations. This was the case of Kosovo, a state struggling for interna- 
tional recognition, whose national sports bodies managed to receive recognition from the most important international sports organizations such as FIFA or the International Olympic Committee. As Kosovo's acting Minister of Foreign Affairs stated about Kosovo's participation in the Rio 2016 Olympic Games, "the sight of our athletes marching in Rio de Janeiro will be the pinnacle of state-building for Kosovo" (Selimi, 2016). Nation building can be, therefore, assessed as just another goal of the domestic dimension of sports diplomacy. Of course, in this case, the context of national pride can also be recognized.

Sports exchanges, sports development aid, foreign sports investments and global recognizability of sports teams and athletes are another methods of sports diplomacy directed at shaping the expected external image of a state. Foreign sports investments are mostly about investing in sports teams or engaging in sponsoring overseas, while global recognizability of athletes, leagues or teams is rather an asset than a method explicitly, however states in its possession may benefit from private initiatives in terms of strengthening their own nation brand. Sports exchanges as a method of sports diplomacy have also been used to manage bilateral relations between states, particularly in the past when international sports competition was less intense than these days. They are about establishing people-to-people contacts in the field of sport, which are meant to foster mutual understanding between engaged nations (Kobierecki, 2018: 60; 67). Sports development aid is to some extent interrelated with sports exchanges since it is also about contacts. It involves donating sports equipment or financing construction of sports venues, sending experts to share their knowledge etc. Such aid as a means of public diplomacy is based on the assumption that it symbolizes links and builds proximity between the people engaged (Zaharna, 2009: 94).

In case of hosting sports events and successful performance in international sport internal dimension is very apparent as they speak in favour of national superiority and foster national pride. In case of other methods, the internal dimension is definitely not as evident, but still noticeable. Sports development aid may be associated with society's internal need to share their prosperity, thus, acting as a feel-good factor. Sports exchanges, on the other hand, facilitate contacts between people from two or more nations. Directly, their goal is to foster other people's understanding of 'our' country, but simultaneously such exchange might foster 'our' understanding for other nations, thus having a domestic effect as well. An example of this method, and at the same time of international recognizability of sport, refers to former Chinese basketball player Yao Ming. The Chinese government supported him as a representative of Chinese culture, modernity and development (Murray, 2013: 13). Yao is believed to have helped to improve China's image in the United States, but simultaneously to improve the way United States were perceived by the Chinese - as a country which received their national hero well (Zhang, 2013: 228-229). It might not have been the prime motivation of the Chi- 
nese government, but definitely the situation reveals domestic dimension of this branding sports diplomacy method.

Internal dimension of foreign sports investments could be witnessed in Poland in 2018 when Polish racing driver Robert Kubica's comeback to F1 after a serious injury was at stake. State-owned oil company Orlen decided to sign sponsorship agreement with F1 team Williams to support Kubica in his comeback which was long awaited by Polish fans. Declared, official reasons for Orlen's engagement were strengthening its brand outside Poland and to show its aspirations as a global oil company (Furman, 2018), but an attempt to satisfy the needs of Polish fans (and voters) appears to be a reasonable explanation as well, particularly considering that a month earlier a tape was revealed, on which Polish Prime Minister (at the time bank's director) Mateusz Morawiecki spoke on Kubica's accident and his unwillingness to invest in F1. Shortly after, Morawiecki arranged a meeting with Kubica, after which the driver declared "no hard feelings" (RP, 2018). Of course, there is no proof for direct government's engagement in Kubica's comeback, but since it became one of the prime topics in Polish media, it may be assumed that it has been convenient for the government, which on the other hand is in control of Orlen. In both cases of Robert Kubica and Yao Ming, there is also an issue of national pride. These days globally successful athletes may serve as national heroes and their successes on global stage become prime topics in national media. In case of Kubica, his recovery after he nearly died in an accident is at the same time a touching story of determination. Therefore, apart from communicating to the external public, such sports diplomacy is also about communicating to the domestic public.

\section{Conclusions}

The research presented in the article included analysis of sports diplomacy understood as a means of managing relations with other countries and shaping the external perception of a state, from the perspective of possible internal implications. The concept of domestic dimension of public diplomacy proved to be useful in explaining this, since sports diplomacy is regarded as a sub-category of public diplomacy.

As a result of the research, it has been observed that both sports diplomacy directed at shaping relations with other countries and at influencing international image of a state, apart from their external dimensions, also have an effect on domestic public. In case of the first type of sports diplomacy, it is mostly about testing the society concerning its willingness and readiness for a change in the state of relations with another country. Another effect might be connected with creating national unity, for example in reference to an external enemy. When branding sports diplomacy is considered, external sports diplomacy often served the domestic purposes of creating or restoring national pride and unity, or nation building. Often, it was connected to goals of the political leaders in their struggle to remain in power. 
The character of the research did not allow to observe how common the domestic dimension of sports diplomacy is. However, in many of the presented examples it was in fact difficult to say whether it were external or domestic goals that were the main motivation of respective sports diplomacy endeavours. Therefore, it may be assumed that in most sports diplomacy activities at least a minor domestic effect or motivation is present. As a result, the hypothesis stating that sports diplomacy despite being a foreign policy tool is not separated from internal policy has been confirmed.

\section{Bibliography}

Alekseyeva A. (2014), Sochi 2014 and the rhetoric of a new Russia: image construction through mega-events, "East European Politics", No. 30(2), pp. 158-174, DOI: https://doi.org/10.1080 /21599165.2013.877710.

Allison L. (1994), The Olympic Movement and the End of the Cold War, "World Affairs", No. 157(2), pp.92-98.

Allison L., Monnington T. (2005), Sport, prestige and international relations, [in:] The Global Politics of Sport. The role of global institutions in sport, edit. L. Allison, London.

Anholt S. (2009), The Anholt-GfK Roper Nation Brands Index SM 2009 Report, https://www.eda.admin.ch/content/dam/eda/de/documents/topics/Switzerland_2009_NBI_Report_08-31-2009. pdf [access on: 24.05.2017].

Arnold R., Foxall A. (2014), Lord of the (Five) Rings. Issues at the 2014 Sochi Winter Olympic Games, "Problems of Post-Communism", No. 61(1), pp.3-12, DOI: https://doi.org/10.2753/ PPC1075-8216610100.

Black D., Peacock B. (2013), Sport and Diplomacy, [in:] The Oxford Handbook of Modern Diplomacy, edit. A.F. Cooper, J. Heine, R. Thakur, Oxford.

Bodet G., Lacassagne M. F. (2012), International place branding through sporting events: A British perspective of the 2008 Beijing Olympics, "European Sport Management Quarterly", No. 12(4), pp. 357-374, DOI: http://dx.doi.org/10.1080/16184742.2012.693114.

Book K. (2014), The Sochi Winter Games: Marketing and Sustainable Development - Or Neither Nor?, [in:] The Sochi Predicament: Contexts, Characteristics and Challenges of the Olympic Winter Games in 2014, edit. B. Petersson, K. Vamling, Newcastle upon Tyne.

Cha V.D. (2009), Beyond the Final Score. The Politics of Sport in Asia, New York.

Cull N.J. (2008), The Public Diplomacy of the Modern Olympic Games and China's Soft Power Strategy, [in:] Owning the Olympics. Narratives of the New China, edit. M.E. Price, D. Dayan, Ann Arbor.

Davies D.J. (2011), 'Go China! Go!: Running Fan and Debating Success During China's Olympic Summer, [in:] The Beijing Olympics: Promoting China. Soft and Hard Power in Global Politics, edit. K. Caffrey, London.

Dembek A., Włoch R. (2014), The Impact of a Sports Mega-Event on the International Image of a Country: the Case of Poland Hosting UEFA Euro 2012, "Perspectives", No. 22(1), pp. 33-47.

Drachman E.R., Shank A. (1997), Presidents and Foreign Policy. Countdown to 10 Controversial Decisions, Albany.

Furman T. (2018), Kubica w Formule 1. Znamy szczegóły umowy Orlenu $z$ Williamsem, https:// www.rp.pl/Biznes/181129754-Kubica-w-Formule-1-Znamy-szczegoly-umowy-Orlenu-zWilliamsem.html [access on: 27.11.2018].

Gilboa E. (2008), Searching for a Theory of Public Diplomacy, "Annals of the American Academy of Political and Social Science", No. 616(1), pp. 55-77, DOI: 10.1177/0002716207312142 
Golubchnikov O. (2016), The 2014 Sochi Winter Olympics. Who stands to gain?, [in:] Global Corruption Report: Sport, London.

Golubchnikov O., Slepukhina I. (2014), Russia - Showcasing a 'Re-Emerging'State?, [in:] Leveraging Legacies from Sports Mega-Events. Concepts and Cases, edit. J. Grix, Basingstoke.

Grix J., Brannagan P.M., Houlihan B. (2015), Interrogating States' Soft Power Strategies: A Case Study of Sports Mega-Events in Brazil and the UK, "Global Society", No. 29(3), pp. 463-479, DOI: http://dx.doi.org/10.1080/13600826.2015.1047743.

Gunter M.M. (2011), Armenian History and the Question of Genocide, New York.

Guthrie-Shimizu S. (2013), Japan and the 2012 London Olympics: Ambitions and Anxieties of a Nation Aspiring to Reprise Olympic Glory, "The International Journal of the History of Sport", No. 30(15), pp. 1758-1768, DOI: https://doi.org/10.1080/09523367.2013.796454.

Hong F. (2007), Communist China and the Asian Games 1951-1990: The Thirty-nine Year Struggle to Victory, [in:] Sport, Nationalism and Orientalism. The Asian Games, edit. F. Hong, Abingdon.

Houlihan B. (2004), Politics and Sport, [in:] Handbook of Sports Studies, edit. J. Coakley, E. Dunning, London.

Huijgh E. (2016), Public Diplomacy, [in:] Sage Handbook of Diplomacy, edit. C.M. Constantinou, P. Kerr, London.

Johns A.L. (2014), Introduction. Competing in the Global Arena: Sport and Foreign Relations since 1945, [in:] Diplomatic Games. Sport, stagecraft, and international relations since 1945, edit. H.L. Dichter, A.L. Johns, Lexington.

Keim M. (2003), Nation Building at Play: Sport as a Tool for Social Integration in Post-apartheid South Africa, Vol. 4, Oxford.

Kobierecki M.M. (2018), Dyplomacja sportowa. Sport w działaniach dyplomatycznych państw i aktorów niepaństwowych, Łódź.

Koller D.L. (2008), How the United States Government Sacrifices Athlete's Constitutional Rights in the Pursuit of National Prestige, "Bringham Young University Law Review", p. 1465.

Lai Lee A. (2010), Did the Olympics help the nation branding of China? Comparing public perception of China with the Olympics before and after the 2008 Beijing Olympics in Hong Kong, "Place Branding and Public Diplomacy", No. 6(3), pp. 207-277, DOI: https://doi.org/10.1057/ pb.2010.21.

LSE European Institute (2016), Petrit Selimi: The sight of our athletes marching in Rio de Janeiro will be the pinnacle of state-building for Kosovo, http://blogs.lse.ac.uk/europpblog/2016/03/29/ petrit-selimi-the-sight-of-our-athletes-marching-in-rio-de-janeiro-will-be-the-pinnacle-ofstate-building-for-kosovo/ [access on: 26.11.2018].

Lu Y-N. (2011), The Representation of the 2008 Beijing Olympic Games: The Rise of China's Soft Power, [in:] China's Quiet Rise. Peace through Integration, edit. B. Guo, C-C. Teng, Lanham.

Macintosh D., Hawes M. (1994), Sport and Canadian Diplomacy, Montreal-Buffalo-London.

Merkel U. (2017), Sport as a foreign policy and diplomatic tool, [in:] Routledge Handbook of Sport and Politics, edit. A. Bairner, J. Kelly, J. Woo Lee, Abingdon.

Müller M. (2014), Introduction: Winter Olympics Sochi 2014: what is at stake?, "East European Politics”, No. 30(2), pp. 153-157, DOI: https://doi.org/10.1080/21599165.2014.880694.

Murray S. (2013), Moving Beyond the Ping-Pong Table: Sports Diplomacy in the Modern Diplomatic Environment, "PD Magazine", No. 9, pp. 11-16.

Murray S. (2018), Sports Diplomacy: Origins, Theory and Practice, London.

Murray S., Pigman G.A. (2014), Mapping the relationship between international sport and diplomacy, "Sport in Society", No. 17(9), pp. 1098-1118, DOI: https://doi.org/10.1080/17430437 .2013.856616.

Ociepka B. (2008), Dyplomacja publiczna jako forma komunikowania międzynarodowego, [in:] Dyplomacja publiczna, edit. B. Ociepka, Wrocław. 
Orttung R.W., Zhemukhov S. (2014), The 2014 Sochi Olympic mega-project and Russia's political economy, "East European Politics", No. 30(2), pp. 175-191, DOI: https://doi.org/10.1080/21 599165.2013.853662.

Pamment J. (2013), New Public Diplomacy in the 21st Century. A Comparative study of policy and practice, Abingdon.

Persson E., Petersson B. (2014), Political myth taking and the 2014 Winter Olympics in Sochi: Olympism and the Russian great power myth, "East European Politics", No. 30(2), pp. 192-209, DOI: https://doi.org/10.1080/21599165.2013.877712

Petersson B. (2014), Still Embodying the Myth? Russia's Recognition as a Great Power and the Sochi Winter Games, "Problems of Post-Communism", No. 61(1), pp. 30-40, DOI: https://doi. org/10.2753/PPC1075-8216610102.

Riordan J. (2010), Sport and Politics in Russia and the Former Soviet Union, [in:] Sport, Representation and Evolving Identities in Europe, edit. P. Dine, S. Crosson, Oxford.

Rowe D. (2011), Global Media Sport. Flows, Forms and Futures, London.

RP, Kubica po spotkaniu z premierem: Polska zawsze wspiera swoich, https://www.rp.pl/Aferatasmowa/181019458-Kubica-po-spotkaniu-z-premierem-Polska-zawsze-wspiera-swoich. html [access on: 27.11.2018].

Trunkos J., Heere B. (2017), Sport Diplomacy: A Review of How Sports Can Be Used to Improve International Relationships, [in:] Studies in Sport Diplomacy, edit. C. Esherick, R.E. Baker, S. Jackson, M. Sam Case, Morgantown.

Wardęga J. (2014), The Image of Beijing Olympic Games as Constructed in Chinese Media, [in:] Media in China. China in Media. Processes, Strategies, Images, Identities, edit. A. Zemanek, Kraków.

Werner L.A. (1989), Media, Sports, and Society: The Research Agenda, [in:] Media, Sports, and Society, edit. L.A. Werner, Newbury Park.

Yu Y. (2010), Olympic Aspirations: Reconstructed Images, National Identity and International Integration, "The International Journal of the History of Sport", No. 27(16-18), pp. 2821-2841, DOI: https://doi.org/10.1080/09523367.2010.508272.

Zaharna R.S. (2009), Mapping out a Spectrum of Public Diplomacy Initiatives. Information and Relational Communication Frameworks, [in:] Routledge Handbook of Public Diplomacy, edit. N. Snow, P.M. Taylor, New York.

Zhang Q. (2013), Sports Diplomacy: The Chinese Experience and Perspective, "The Hague Journal of Diplomacy”, No. 8, pp. 211-233, DOI: https://doi.org/10.1163/1871191X-12341257

Abstract: Sports diplomacy is a tool of foreign policy. Similarly to public diplomacy, for which sports diplomacy is a sub-category, it may also have a domestic dimension. The objective of the research was to overview key types of sports diplomacy activities pursued by governments from the perspective of their internal political significance and to answer the research question whether sports diplomacy may be used to influence the domestic public. The hypothesis to be verified within the research stated that sports diplomacy, despite being a foreign policy tool, is not separated from the internal policy.

The research allowed for confirmation of the hypothesis. It has been observed that both sports diplomacy directed at shaping relations with other countries and at influencing the international image of a state, apart from their external dimensions, also have an effect on the domestic public. It may be about testing the society's willingness and readiness for a change in the state of relations with another country or might be connected with creating national unity.

Keywords: sport, politics, sports diplomacy, public diplomacy, domestic politics

Article submitted: 6.12.2018; article accepted: 19.05.2019. 